\title{
Airway Obstruction after Laryngeal Burn Induced by Swallowing Hot Food
}

\author{
Jung Hoon Lee, Sang Ki Min, Hoon Shik Yang, and Sei Young Lee \\ Department of Otorhinolaryngology-Head and Neck Surgery, College of Medicine, Chung-Ang University, Seoul, Korea
}

\section{음식물에 의한 후두화상 후 발생한 기도폐쇄 1 예}

이정훈 · 민상기 · 양훈식 · 이세영

중앙대학교 의과대학 이비인후-두경부외과학교실

\author{
Received October 29, 2014 \\ Revised November 17, 2014 \\ Accepted November 17, 2014 \\ Address for correspondence \\ Sei Young Lee, MD \\ Department of Otorhinolaryngology- \\ Head and Neck Surgery, \\ College of Medicine, \\ Chung-Ang University, \\ 102 Heukseok-ro, Dongjak-gu, \\ Seoul 06973, Korea \\ Tel $+82-2-6299-1765$ \\ Fax $+82-2-825-1765$ \\ E-mail syleemd@cau.ac.kr
}

Thermal burns of the larynx after swallowing hot foods or drinks are frequently common in children, but are known to be extremely rare in adults. We report the case of a male adult who, upon swallowing hot food, experienced a burn of the larynx with airway obstruction. Since airway obstruction usually occurs within hours of burn of the larynx, the importance of persistent airway management is emphasized in this case.

Korean J Otorhinolaryngol-Head Neck Surg 2015;58(9):634-6

Key Words Airway obstruction · Dyspnea $\cdot$ Laryngeal burn.

\section{서 론}

후두폐쇄를 일으키는 원인은 다양하지만, 가장 흔한 원인 은 기관 내 삽관의 후유증으로 의한 만성 폐쇄이며, ${ }^{1)}$ 드물게 온도나 화학적 요인에 의한 손상으로 인해 기도폐쇄가 발생 할 수 있다. Courey ${ }^{2)}$ 에 따르면 기도폐쇄의 원인은 크게 급성 과 만성으로 나눌 수 있는데, 후두나 기관에서 발생하는 염 증이나 자가면역질환, 종양 등이 주로 만성 폐쇄를 일으키며, 급성폐쇄는 교통사고와 같은 외상 또는 열이나 화학물질 등 에 의한 후두 손상에 의해 발생할 수 있다. 후두의 화상은 열 에 의한 직접적인 손상을 비롯하여 연소되면서 발생한 독성 물질 흡인 및 기관 내 삽관이 합쳐져 복잡한 기전을 가지게 되며 후두에 울혈과 부종을 일으켜 후두 협착을 일으킬 수 있다. ${ }^{13)}$ 일반적인 후두화상과 달리 뜨거운 음식을 삼킬 때에 도 후두화상을 유발할 수 있는데, 이러한 후두화상은 소아 에서는 드물지 않게 관찰되지만, 성인에서는 매우 드문 현상
이다.4-6) Alpay 등헤에 의하면 현재까지 보고된 음식물에 의 한 성인의 후두화상은 모두 3예뿐이었으며 모두 고형의 음식 물이 아닌 뜨거운 물이나 차를 마셔서 발생했었고, 국내에서 도 아직까지 뜨거운 음식에 의한 후두화상은 보고된 바가 없 다. 이에 저자들은 63 세의 남자에서 뜨거운 음식을 삼킨 후 후두화상을 입고 그에 따른 후두부종으로 기도폐쇄가 발생 한 사례를 문헌 고찰과 함께 보고하고자 한다.

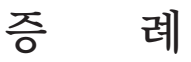

63세 남자가 인후통과 목의 이물감을 주소로 응급실을 방 문하였다. 환자는 내원 5 시간 전에 뜨거운 감자탕을 먹었는 데 너무 뜨거워 바로 뱉어냈다고 했다. 내원 당시 환자의 의 식은 명료하였으며 호흡곤란은 없었다.

이학적 검사상 구강 내와 인후의 이상소견은 없었고 생체 징후도 안정적이었다. 체온은 $37^{\circ} \mathrm{C}$, 심박수는 분당 72 회, 혈압 

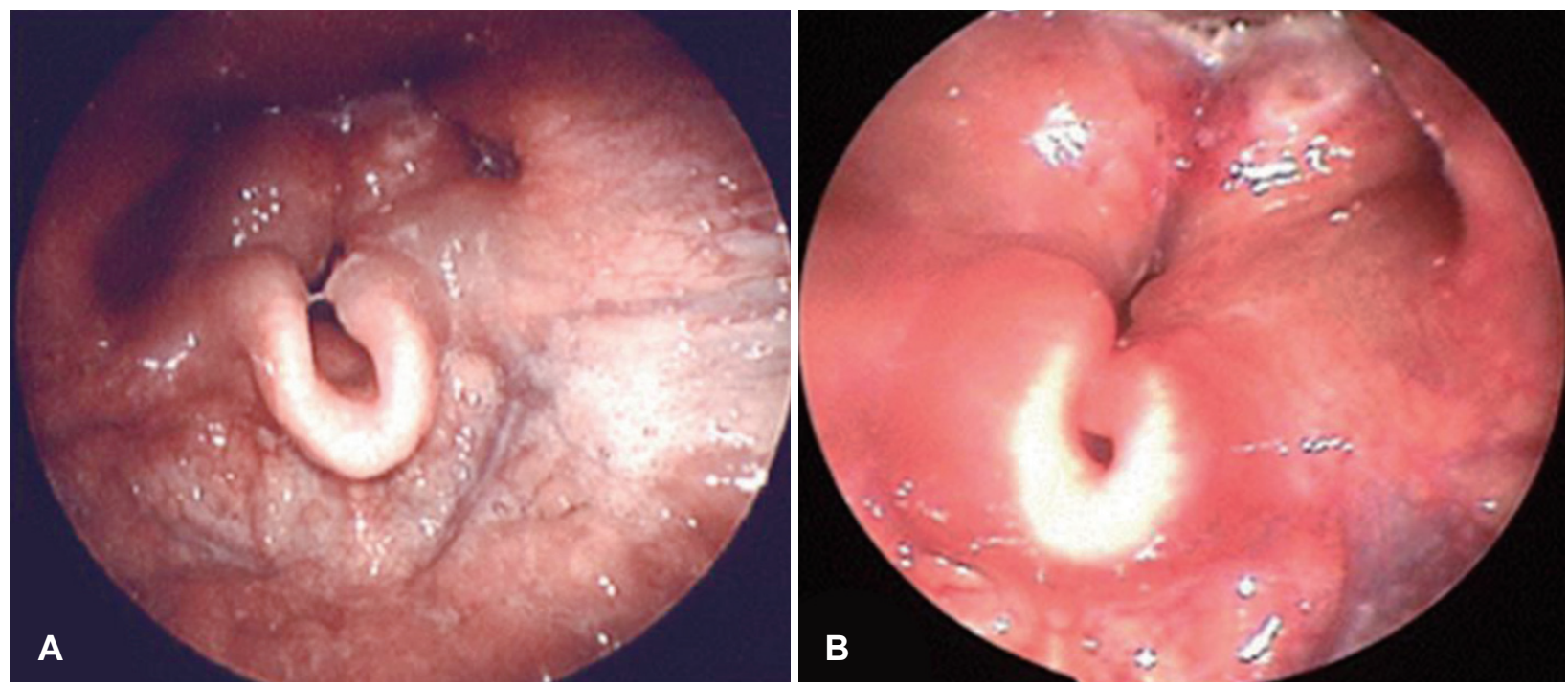

Fig. 1. Laryngoscopic findings of the larynx at admission. Both arytenoids mucosa were mild swollen and erythematous (A). After $1 \mathrm{hr}$, in spite of injecting steroid, swelling and erythema of arytenoids mucosa, aryepiglottic folds and surrounding structures became more aggressive and there was almost complete stricture of the airway (B).

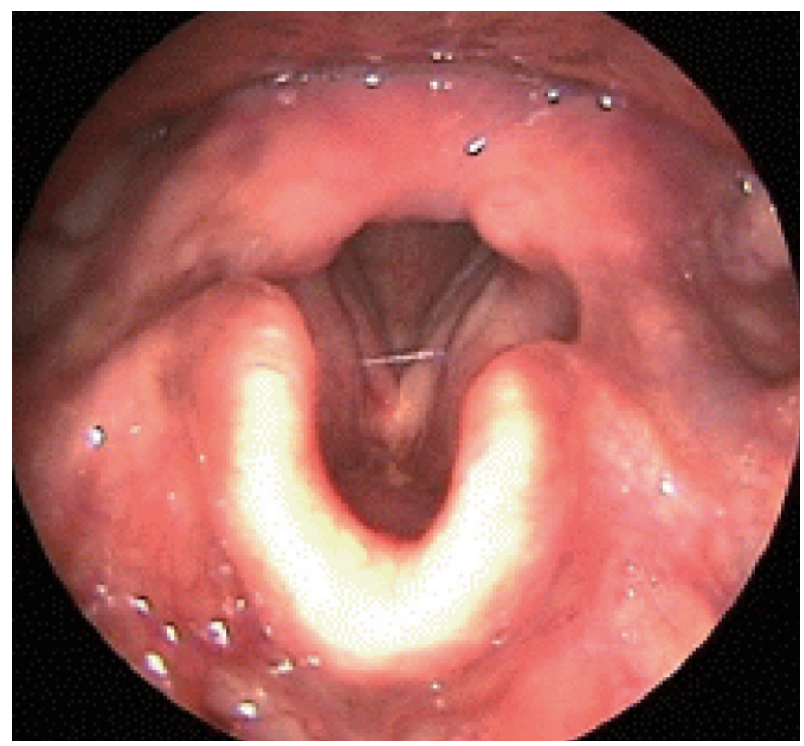

Fig. 2. Laryngoscopic finding at 2 weeks after the thermal injury reveals a normal larynx.

은 142/82 mm Hg, 산소포화도는 96\%였다. 환자는 3년 전 고 혈압과 당뇨를 진단받고 약물 복용 중이었다.

내원 시 시행한 후두경에서 양쪽 피열근 점막의 경미한 부 종이 있었으며(Fig. 1A), 덱사메타손 $5 \mathrm{mg}$ 을 iv bolus로 투 여하고 경과 관찰하였다. 한 시간 후 호흡곤란과 함께 연하 통이 발생하였고, 인후통이 악화되었다. 후두경검사상 피열 근 점막과 피열후두개 주름과 주변 구조물에 발적과 부종이 있었으며 기도는 거의 완전히 협착되어 있었다(Fig. 1B). 따 라서 환자는 기도유지를 위해 기관 내 삽관을 받았다.

입원 후 환자는 5 일 동안 덱사메타손 $(5 \mathrm{mg} / \mathrm{day})$ 과 세파계 항생제 $(3 \mathrm{~g} / \mathrm{day})$ 를 투여받았고 후두 부종의 변화를 매일 후
두경을 통해 관찰하였다. 이후 후두경 검사를 반복 실시하여 피열근 점막의 부종이 줄어든 것을 확인하고 기관 내 삽관 된 튜브를 4일 후에 제거하였다. 상부위장관내시경 검사상 식도 의 이상소견은 발견되지 않았다. 환자는 입원 6 일 후 퇴원하 였고, 퇴원 2주 후 후두화상은 점막에 반흔 없이 완전히 회 복되었다(Fig. 2).

\section{고 찰}

후두화상은 주로 폐쇄된 공간에서 일어나는 화재 사고를 겪은 환자에게 발생되는데 이는 화상 시 산소가 적게 들어가 고 뜨거운 증기나 공기, 독성 화학물질에서 나오는 독성 물 질을 직접 흡입함으로써 생긴다. 흡인화상에 의한 후두협착은 성문하부, cuff, 기관 누공 부분에서 주로 발생한다. Kim 등1) 과 다른 저자들의 논문에 따르면 후두 협착은 81 명 중 10 명인 약 $12 \%$ 정도 발생하며 그 중에 $80 \%$ 인 8 명의 환자는 기관절 개술을 시행받았다. 흡인화상의 경우 폐에 합병증을 일으킬 수도 있으며 미국 내에서 3 천 개의 증례가 보고되었다. 이는 20세 이하 사망원인 3 위를 차지한다.7)

반면 뜨거운 음식을 먹거나 음료를 마셔 직접 열손상을 받 은 후두화상은 후두에 손상을 일으키는데, 특히 성문상부의 손상이 크다. 이 손상은 모세혈관 투과성을 증가시키고 염증 을 일으키며 무성증, 연하곤란, 침흘림 등의 증상을 가져온 다. 뜨거운 음식이나 음료에 의한 후두화상은 대부분 소아에 서 발생하고 성인의 경우는 거의 없어서 학계에 보고될 정도 의 증례는 3건뿐이다. ${ }^{6}$ 어린 소아의 후두와 인두는 C2 레벨 에서 후두 덮개와 붙어 있는 반면, 성인은 C6 레벨에 있기 때 
문에 소아에서 구강까지의 거리가 짧다. 또한 소아는 후두 연골의 석회화가 발달되지 않아서 손상에 더 취약하다.,6) 앞 서 어른에서 보고된 3건의 증례는 모두 뜨거운 음료에 의한 화상이었고 뜨거운 음식에 의한 경우는 없었다. 왜냐하면 뜨 거운 음식은 상대적으로 구강 내를 통과하기 힘들고 뜨거운 음료에 비해 뱉어내기가 쉽기 때문이다.

후두는 구강에 비해 열기에 더 많은 영향을 받게 되고 후 두화상은 응급상황인 상기도 폐쇄를 일으킬 수 있다. 진단이 늦어지면 저산소증에 의한 허혈성 뇌 손상을 일으킬 수 있고 최악의 경우 환자가 사망할 수도 있기 때문에 신속한 진단과 적절한 치료가 필요하다. ${ }^{8)}$ 일반적으로 뜨거운 음식에 의한 후두화상은 매우 드물기 때문에 표준화된 치료법이 없고 따 라서 일반적인 후두화상 치료법을 따라야 한다. 하지만 기도 폐쇄가 발생할 수도 있기 때문에 기도확보를 위해 기관 내 삽 관과 기관절개술을 항상 준비해 두어야 한다. ${ }^{9)}$ Goto 등 ${ }^{4}$ 과 그의 동료들은 소아에서 많이 발생하는 후두화상은 환자를 처음 접하는 의사가 소아과 의사이기 때문에 기관절개술보다 는 기관 내 삽관술을 시도한다고 보고하였다. 일반적으로 흡 인에 의한 상기도 화상의 경우 지연성 호흡곤란과 폐의 손상 이 동반되는 경우가 흔하기 때문에 조기에 기관절개술을 시 행하여야 하는 경우가 많지만, 음식물에 의한 상기도 화상은 화상이 발생한 부위 이외에는 다른 부위는 정상적이므로 기 도폐쇄가 발생하였을 때 기관 내 삽관이 좀 더 유리한 것으 로 알려져 있다. 저자들도 호흡곤란을 예방하기 위해서 기관 내 삽관을 시행하고 후두경을 통해 후두덮개와 피열근 부종 의 호전양상을 관찰했다. Alpay 등희 의 논문에서 증기흡인에 의한 화상에서 기도확보 이후에 항생제와 스테로이드를 치료 에 사용했다고 하였고 저자들도 역시 환자가 입원해 있는 동 안 덱사메타손과 세파계 항생제로 치료하였다. 이 증례의 경 우 후두부종을 줄이기 위해 초기에 스테로이드를 주사하였 음에도 불구하고 초기에 관찰된 부종의 정도가 나아지지 않 고 환자의 증상과 후두경상의 결과도 악화되었다.

Brahams ${ }^{8}$ 에 따르면 상기도 화상에 의한 호흡곤란은 손 상후 수시간이 지난 후에 악화되기도 한다. 따라서 입과 그 주변에 심각한 화상을 입은 경우에는 환자 내원 당시 호흡곤 란이 없다고 하더라도 기도폐쇄에 의한 증상이 늦게 나타날 수 도 있고 기도폐쇄가 급격히 진행될 수 있기 때문에 중환자실에
서 면밀한 관찰이 필요하다. ${ }^{5)}$ 따라서 뜨거운 음식에 의한 후두 화상으로 점막부종이 일어나는 경우에도 더딘 진행으로 지 연된 기도폐쇄를 일으킬 수 있으며 갑자기 악화될 수 있다. 이러한 경우도 역시 기도 점막의 부종이 감소되기 시작할 때 까지 면밀한 관찰이 필요하다.

후두화상의 임상양상과 검사결과들이 후두염과 비슷하다 는 Kulick 등이 의 보고에 따라 후두염의 가장 흔한 원인인 H. influenza에 대한 경험적 항생제를 사용하였다. 하지만 Goto 등ㄴ)은 항생제 사용이 내성을 일으킬 수 있다고도 보고하였으 며, Harjacek 등은 모든 배양결과가 음성으로 나왔다고 보고 하였다. 따라서 항생제 사용의 효용성을 검증할 추후 연구가 필요할 것으로 사료된다.

뜨거운 음식을 먹고 목이 따갑다고 오는 성인 환자들은 기 도폐쇄의 가능성이 있으므로 후두부종에 의한 호흡곤란을 막기 위해 항상 후두경 검사를 해야 한다. 또한 후두화상의 급성기에 스테로이드를 주사했다고 하더라도 후두부종에 의 해 호흡곤란이 추후에 발생할 수도 있으므로 환자의 증상과 징후를 지속적으로 관찰하는 것이 필요하다고 사료되었다.

\section{REFERENCES}

1) Kim IW, Choi DJ, Kim TH, Kim BG, Kim YB, Park IS, et al. Laryngotracheal stenosis in burned patients with inhalation injury: analysis of risk factors. Korean J Otorhinolaryngol-Head Neck Surg 2008;51(11):1025-9.

2) Courey MS. Airway obstruction. The problem and its causes. Otolaryngol Clin North Am 1995;28(4):673-84.

3) Kim GR, Lee DG, Chung HY, Park JW, Cho BC, Lee KW. A study of the inhalation injury in Daegu subway fire accident in 2003. Korean J Burn 2003;6(2):75-81.

4) Goto R, Miyabe K, Mori N. Thermal burn of the pharynx and larynx after swallowing hot milk. Auris Nasus Larynx 2002;29(3):301-3.

5) Harjacek M, Kornberg AE, Yates EW, Montgomery P. Thermal epiglottitis after swallowing hot tea. Pediatr Emerg Care 1992;8(6): 342-4.

6) Alpay HC, Kaygusuz I, Karlidag T, Orhan I. Thermal burn of the larynx in an adult following hot water aspiration. Otolaryngol Head Neck Surg 2008;139(1):164-5.

7) Jones JE, Rosenberg D. Management of laryngotracheal thermal trauma in children. Laryngoscope 1995;105(5 Pt 1):540-2.

8) Brahams D. Anaesthesia and the law. Respiratory failure in a young child after aspiration of hot tea. Anaesthesia 1989;44(10):858-9.

9) Dye DJ, Milling MA, Emmanuel ER, Craddock KV. Toddlers, teapots, and kettles: beware intraoral scalds. BMJ 1990;300(6724): 597-8.

10) Kulick RM, Selbst SM, Baker MD, Woodward GA. Thermal epiglottitis after swallowing hot beverages. Pediatrics 1988;81(3):441-4. 